\title{
Cooling Water Lime Softening Plant Optimisation
}

\author{
LL Maswanganyi ${ }^{1}$, F Waanders ${ }^{2}$, E Fosso-Kankeu ${ }^{2}$, T Tamane ${ }^{1}$ and G Gericke ${ }^{1}$
}

\begin{abstract}
Recirculating cooling water is required in a power plant to condense the exhaust steam from the turbine and extract the latent heat as part of the Rankine cycle steam process. Conditioning of the recirculating cooling water is essential to maintain the cooling system free of scaling, fouling and corroding the heat transfer surfaces. A good conditioning treatment for cooling water chemistry control simultaneously reduces scaling, biological fouling, deposition and corrosion on the cooling systems. The current interventions for the control of these concerns has increased the costs accompanying the operation of a cooling water circuit. This lead to the power plant experiencing cooling changes and eventually affected plant performance. A decision by the power plant to optimise the side stream treatment control was initiated. Plant analysis, evaluation was conducted, lime system to the sedimentation plant including other chemicals for the clarifications process were optimised. Finally, a model was developed to assist in plant monitoring and data collection.

The assessment conducted before the optimisation revealed that cooling water flow rates to the plant were inconstant leading to incorrect chemicals being dosed. This resulted in the sedimentation process being ineffective and overall chemistry performance deteriorating. To address the above, flow measurements were verified and chemical dosages using the jar test and lime silo bag test to the plant were conducted. The corrected measurements were incorporated in to the model, giving an indication to the operating team to make corrections and adjustment to the lime side stream treatment keeping the operation of the plant at an optimal level. During the optimisation a $\mathrm{pH}$ increase was observed with clarifier 2 responding quicker than clarifier 1 where the test was conducted.

Optimisation of the cooling water side treatment to control cooling water chemistry will have a positive impact on the power plant performance especially the cooling systems in a power plant.
\end{abstract}

Keywords-Cooling water chemistry conditioning, lime softening, optimisation, side stream treatment

Manuscript received October 5, 2020. This work was supported in part by Eskom Research Testing and Development Water and Applied Chemistry Department and Eskom Power Plant Engineering Institute

L.L Maswanganyi is with School of Chemical and Minerals Engineering, North-West University, Potchefstroom, South Africa

T. Tamane is with Eskom Research Testing and Development

G. Gericke is with Eskom Research Testing and Development

E. Fosso-Kankeu is with the Water Pollution Monitoring and Remediation Initiatives Research Group, School of Chemical and Minerals Engineering, Faculty of Engineering, North-West University, South Africa

F. Waanders is with the Water Pollution Monitoring and Remediation Initiatives Research Group, School of Chemical and Minerals Engineering, Faculty of Engineering, North-West University, South Africa.

\section{BACKGROUND}

Lime plant optimisation project was introduced as a result of plant failures and downtime occurring at the lime handling plant. Lime is dosed in the concentrated cooling water clarifiers to control the alkalinity and hardness of the concentrated cooling water. The unavailability of the lime handling and preparation plant for longer durations is not a desired practice. Lime plant unavailability compromises the long-term plant health in the concentrated recirculating cooling water system. Maintenance and operational challenges are the reason for lime handling plant outages. These challenges are associated with frequent blockages in the lime silo, chemicals and spares unavailability amongst other things.

\section{INTRODUCTION}

Process integration is a systematic technique for reducing water consumption and wastewater generation [1]. This technique involves water regeneration, recycling and reuse [2], with the consideration of chemical concentrations, water flowrates, $\mathrm{pH}$, conductivity, organic carbons and others that may prevent water reuse or recycling within the water network [3].

Chemical treatment is the most common method used to regulate the cooling water chemistry in order to prevent deterioration in plant performance [4-8]. A lime plant is commonly used for cooling water pre-treatment in wet cooled power plants [9]. In the lime softening process chemicals are added to the cooling water so that the scale forming components are reduced [10]. The lime is used to remove alkalinity and hardness salts through precipitation of calcium carbonate and magnesium hydroxide in the clarifiers [11].

Lime reacts with mainly calcium, magnesium and bicarbonates to form scale in the clarifiers, which is then removed by desludging [12]. These reactions take place at about $\mathrm{pH} 10$ [13]. If insufficient lime is added ( $\mathrm{pH}$ lower than 10), the reaction will be incomplete and not all the bicarbonate $\left(\mathrm{HCO}_{3}{ }^{-}\right)$will be removed. If lime is over-dosed ( $\mathrm{pH}$ higher than 10), then the excess will be carried into the cooling water system where the scale forming reactions will occur [13]. Precipitation of heavy metals out of solution is achieved at optimum $\mathrm{pH}$ of 10.2 (McDonald, 2006) where almost all the bicarbonates in a water solution are converted to carbonates $\left(\mathrm{CO}_{3}{ }^{2-}\right)$. Hanekom (2008) indicated in his study that the scale that forms in the cooling water system will generally scale the warmest point in the system i.e. 
the condenser [14].

\section{MATERIALS AND METHODS}

\section{A. The chemistry}

Alkalinity and $\mathrm{pH}$ measurement were used to evaluate the performance of the plant. Alkalinity ( $\mathrm{P}, \mathrm{M}$ and $\mathrm{OH})$, defined as the acid absorbing property of water [15] is related to the optimum $\mathrm{pH}$. $\mathrm{P}$ and $\mathrm{M}$ refer to phenolphthalein and methyl orange indicators respectively whereas $\mathrm{OH}$ measures the hydroxides. $\mathrm{P}$ and $\mathrm{M}$ alkalinity relationship was used to assess the performance of the plant as indicated by Table I. The optimum $\mathrm{pH}$ is achieved when $2 \mathrm{P}=\mathrm{M}$ where only carbonates are available in solution [13].

TABLE I: ALKALINITY RELATIONSHIP

\begin{tabular}{|c|c|c|c|}
\hline $\begin{array}{l}\text { Titration } \\
\text { results }\end{array}$ & $\begin{array}{l}\text { OH } \\
\text { alkalinity }\end{array}$ & $\begin{array}{l}\mathrm{CO}_{3}{ }^{2-} \\
\text { Alkalinity }\end{array}$ & $\begin{array}{l}\mathrm{HCO}_{3}^{-} \\
\text {Alkalinity }\end{array}$ \\
\hline P-Alk & 0 & 0 & $=$ Total Alk \\
\hline $\begin{array}{l}\text { P-Alk = Total } \\
\text { Alk }\end{array}$ & $=$ Total Alk & 0 & 0 \\
\hline $\begin{array}{l}\text { P-Alk is } \\
<1 / 2 \text { Total } \\
\text { Alk }\end{array}$ & 0 & $2 * \mathrm{P}-\mathrm{Alk}$ & $\begin{array}{l}=\text { Total } \\
\text { Alk }-(2 * \text { P-Alk })\end{array}$ \\
\hline $\begin{array}{l}\text { P-Alk is } 1 / 2 \\
\text { Total Alk }\end{array}$ & 0 & $\begin{array}{l}=\text { Total Alk } \\
\text { (Optimum pH) }\end{array}$ & 0 \\
\hline $\begin{array}{l}\text { P-Alk is } \\
>1 / 2 \text { Total } \\
\text { Alk }\end{array}$ & $\begin{array}{l}\text { (2*P-Alk)- } \\
\text { Total Alk }\end{array}$ & $\begin{array}{l}=(\text { Total } \\
\text { Alk }-\mathrm{P}-\mathrm{Alk}) * 2\end{array}$ & 0 \\
\hline
\end{tabular}

\section{B. Dosing system}

Lime is stored in a lime silo at the water treatment plant. The mass of the lime delivered to the plant from the silo during the injection process is unknown due to the level transmitter that is faulty and measuring inaccurate levels. This resulted in the unexpected depletion of the lime. The commercial process is prolonged, leading to operating the plant without any lime dosages. To address the challenge during optimisation, lime silo bag tests were conducted. The tests physically measured the mass of lime that is collected in a bag at fixed time. Table II shows a typical average mass of lime recorded from the lime silo at different percentage openings.

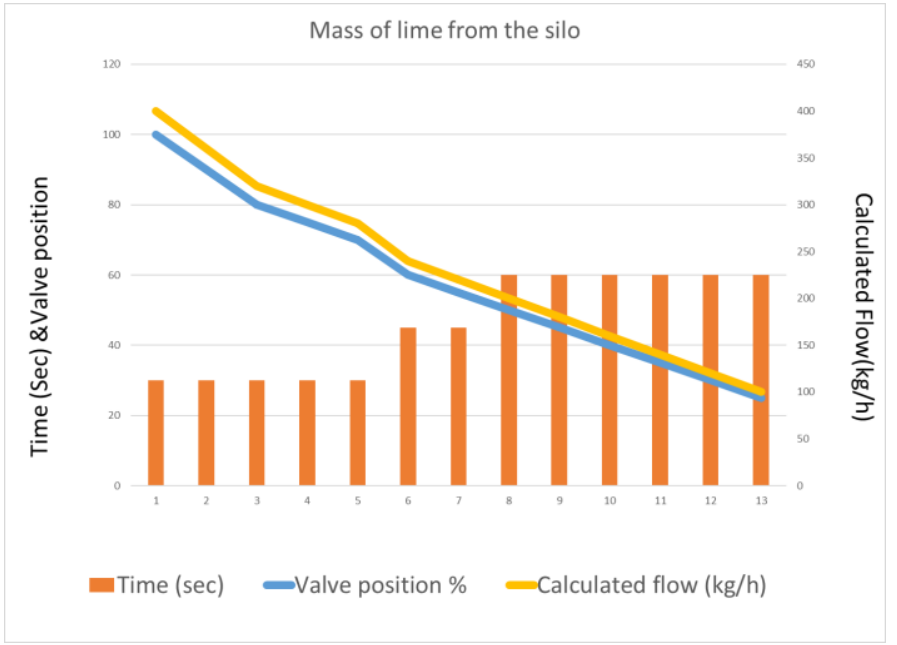

Fig.1: mass of lime from the silo

The data logged in Fig.1 were used to measure the lime dosed to the plant and predict the low levels in the silo. As lime levels drop in the silo, the commercial process can commence to ensure sufficient time for the chemical order to be placed. Chemical unavailability and lime shortages will be reduced if not completely prevented.

\section{Chemical dosages}

Concentrated cooling water (CCW) and dirty water dam (DWD) recovery water samples were collected from the power plant. Lime was dosed with a blend of a flocculent (poly) to enhance the clarification and sedimentation process [16]. Jar test [17] analysis recorded in Fig 2 and 3 was conducted in the laboratory to obtain the optimum dosage ratio between lime and the flocculent. Recirculating cooling water flow was kept constant, whereas different concentration of lime and flocculent (poly) were varied to observe the optimum dosage, for turbidity removal.

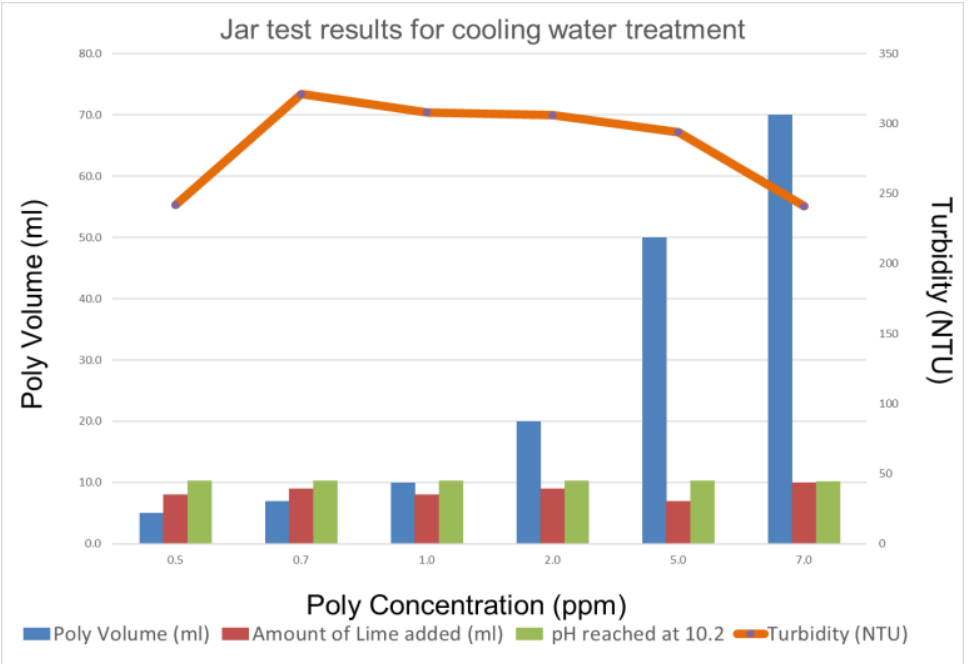

Fig.2: lime and poly Jar test measurements for cw treatment 


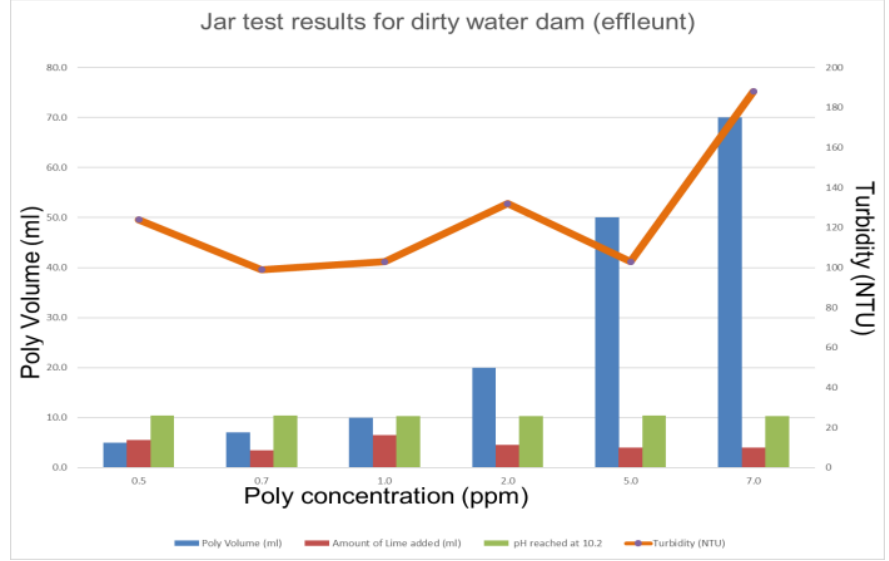

Fig.3: lime and poly Jar test measurements for dwd

The laboratory jar test [18] was used to determine the amount of chemicals that must be dosed to meet the optimum $\mathrm{pH}$ of 10.2 in the plant.

\section{Plant flowrates}

A mass balance of the plant was conducted before the plant can be optimised. The information available from the power plant initial design phase has transformed as new technology immerged, therefore plant current conditions needed to be verified and updated. In addition, the ageing power plants do not have adequate flow meters at critical parts of the plant, and some are obsolete and redundant. A portable flow transmitter [15] was used to measure and acquire the correct flow rates around the plant. Fig.3 shows the flow and mass balance around the concentrated cooling water system.

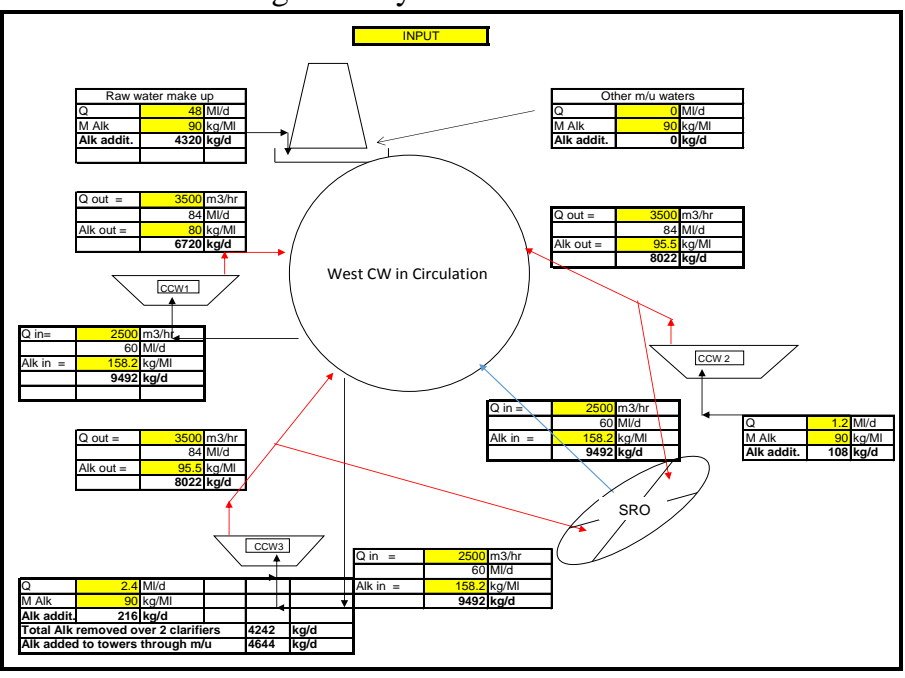

Fig.4: ccw circuit with side stream water balance

\section{E. Data modeling}

The data collected form the plant and results from the laboratory were modelled to ensure the optimum management and control of concentrated cooling water treatment. Table IV focuses on the clarifier flow input. The design CCW flow rate is $10 \%$ of the $\mathrm{CCW}$ system. The required $\mathrm{CCW}$ to be treated is controlled by populating the main feed flowrate in the model. A previous study indicated that circular clarifier optimum flow through velocity should be between $0.7 \mathrm{~m} / \mathrm{s}$ and $1.4 \mathrm{~m} / \mathrm{s}$. The calculated figure on the model should be monitored and verified.

TABLE IV: CCW CLARIFIER FEED FLOW

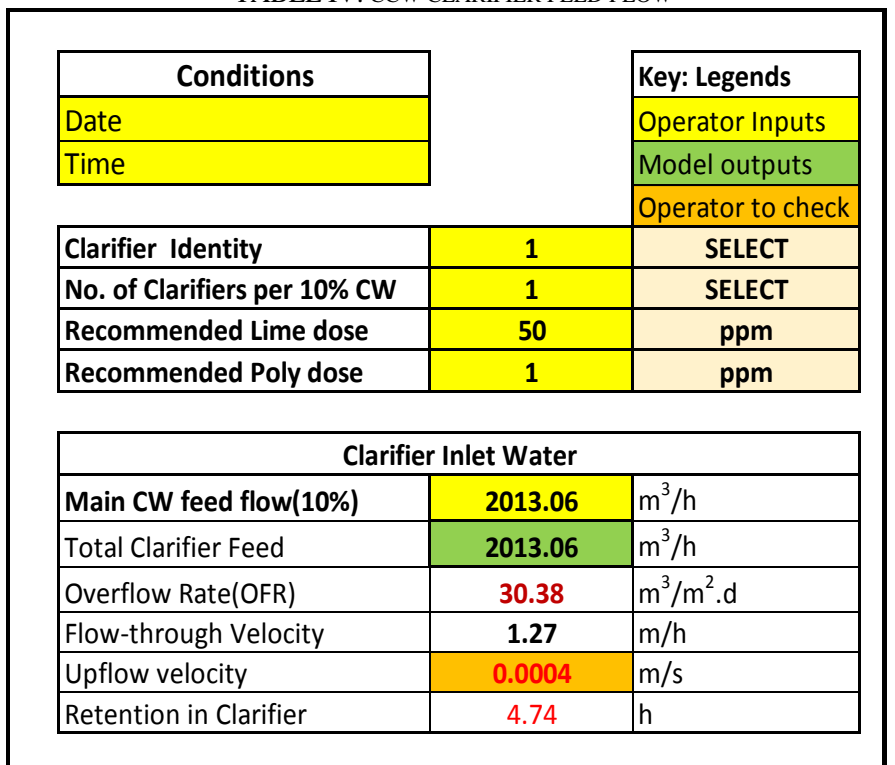

Table V and VI extracted from the model indicate the chemical dosage required for the plant during optimisation as per the jar test laboratory results.

TABLE V: CCW CLARIFIER LIME DOSING RATE

\begin{tabular}{|l|c|l|}
\hline \multicolumn{3}{|c|}{ Lime dosing } \\
\hline Lime type & \multicolumn{2}{|c|}{ Hydrated lime } \\
\hline Concentration & $64 \%$ & $\mathrm{Ca}(\mathrm{OH})_{2}$ \\
\hline Rotary feed opening & $8 \%$ & $100 \%=1250 \mathrm{~kg} / \mathrm{h}$ \\
\hline Feed, $\mathrm{Ca}(\mathrm{OH})_{2}$ & 66 & $\mathrm{~kg} / \mathrm{h}$ \\
\hline Motive water feed & 5049 & $\mathrm{l} / \mathrm{h}$ \\
\hline Slurry concentration & 13.0286 & $\mathrm{~g} / \mathrm{l}$ \\
\hline Slurry concentration in $\mathrm{ppm}$ & 13028.6 & $\mathrm{mg} / \mathrm{l}$ \\
\hline Dilution water supply & 21091 & $\mathrm{I} / \mathrm{h}$ \\
\hline Concentration in dilution tank & 5033 & $\mathrm{mg} / \mathrm{l}$ \\
\hline Clarifier feed valve position & $20 \%$ & $100 \%=100 \mathrm{~m}^{3} / \mathrm{h}$ \\
\hline Lime Clarifier Feed & 20000 & $\mathrm{l} / \mathrm{h}$ \\
\hline Concentration per clarifier & 50.0 & $\mathrm{ppm}$ \\
\hline
\end{tabular}

The dosing of lime is controlled by using a $\mathrm{pH}$ transmitter located on the outlet of each clarifier to maintain the $\mathrm{pH}$ levels between 10.2 and 10.4 [19]. M-alkalinity is used as a measure of efficiency in the clarifier and an indication of the concentrations levels of calcium bicarbonate salts in the CCW. 
TABLE VI: CCW CLARIFIER POLY DOSING RATE

\begin{tabular}{|c|c|c|}
\hline \multicolumn{2}{|c|}{ Poly/Coagulant Aid } & \\
\hline Poly type & Polyelectrolyte & \\
\hline Chemical name & Sudfloc TM & $\begin{array}{l}\text { Manual } \\
\text { Caliberation }\end{array}$ \\
\hline Concentration & $100 \%$ ppm & \\
\hline Pump dosing & $7 \% 100 \%=10001 / \mathrm{h}$ & $17 \%$ \\
\hline Feed flow & $68.4 \mathrm{I} / \mathrm{h}$ & 8.5 \\
\hline Poly Makeup Water & $1 / \mathrm{h}$ & 4.222 \\
\hline Poly Dilution Water & $9798 \mid / / h$ & \\
\hline Poly Clarifier Feed & $9471 \mid / / h$ & Poly Dosage \\
\hline Clarifier Poly Dosage & $34.0 \mathrm{ppm}$ & \\
\hline
\end{tabular}

The requirement for the lime and poly dosage is calculated according to the dilution chemistry Equation 1. Dosing rates for lime and poly calculations are shown in Table V and VI on the model.

$$
\mathrm{C}_{1} \mathrm{~V}_{1}=\mathrm{C}_{2} \mathrm{~V}_{2}
$$

Eq. 1

Where:

$\mathrm{C}_{1}=$ original concentration of the solution, before it is watered down or diluted.

$\mathrm{C}_{2}$ = final concentration of the solution, after dilution.

$\mathrm{V}_{1}=$ volume about to be diluted

$\mathrm{V}_{2}=$ final volume after dilution

Two concentrated cooling water clarifiers were considered for the optimisation test, clarifier 1 and 2 . Lime was mixed in to the mixing tank from the silo and transferred as slurry in to the dilution tank. From the dilution tank lime was pumped to clarifier 1 and 2 center cone where it is mixed with $10 \%$ concentrated cooling water. Samples were collected from the center cone and the clarifier launder for performance management.

\section{RESULTS AND DISCUSSIONS}

The lime side treatment softening in a power plant is designed to treat $10 \%$ of the stations concentrated cooling water to ensure that the cooling water meets chemistry specification standards after treatment [10]. As the makeup water chemistry changes and other water management regulations take effect, the chemistry changes gradually. This resulted in ineffective treating of the $\mathrm{CCW}$. The lime optimisation trial conducted at the power plant intended to improve and advice on the treatment of the side stream softening. The study was conducted between September to December 2019. A portable $\mathrm{pH}$ meter was used in the plant to assist in making lime dosing adjustment until the optimum $\mathrm{pH}$ is achieved. Fig 5 shows the behavior from clarifier 1 center cone $\mathrm{pH}$ after the optimisation process commenced. The measured $\mathrm{pH}$ from the beginning of the trial was below the optimum $\mathrm{pH}$ although in the afternoon an increase in $\mathrm{pH}$ was observed. The same trend to confirm clarifier1 behavior was observed from Fig 6. Clarifier 1 treated water $\mathrm{pH}$ slowly increased. In Fig 7 the $\mathrm{pH}$ increased to above the optimum $\mathrm{pH}$, the same pattern was observed as in Fig 8. This was a clear indication that the lime slurry was slowly going through and the observed change was in less than 2 hours.

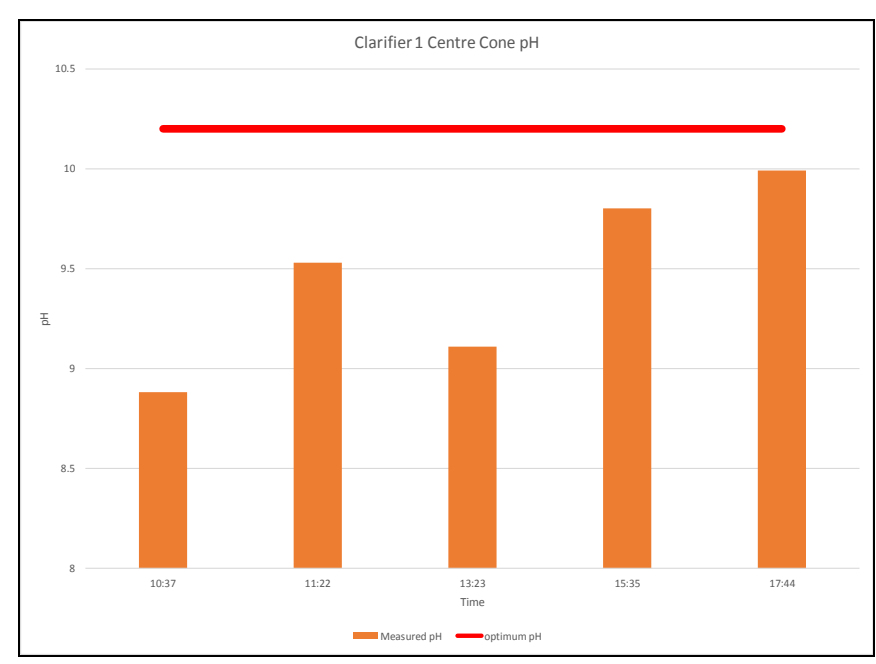

Fig.5: clarifier 1 center cone $\mathrm{pH}$

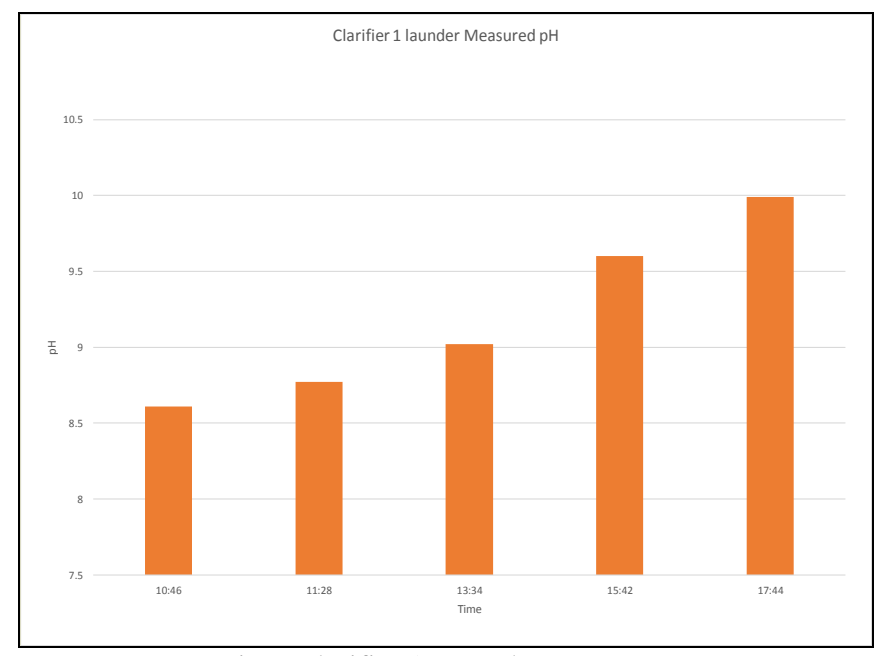

Fig.6: clarifier 1 treated water $\mathrm{pH}$

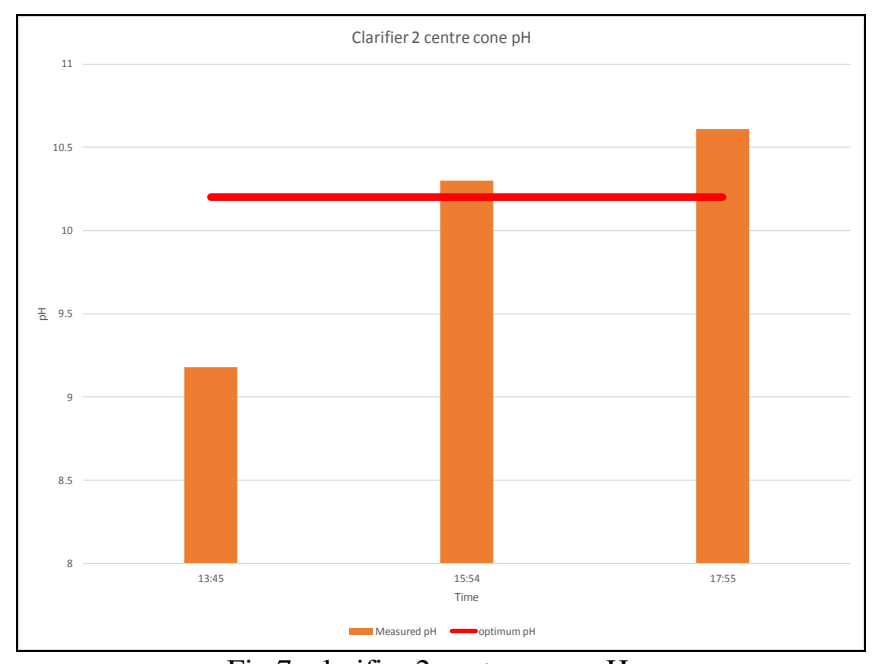

Fig.7: clarifier 2 center cone $\mathrm{pH}$ 


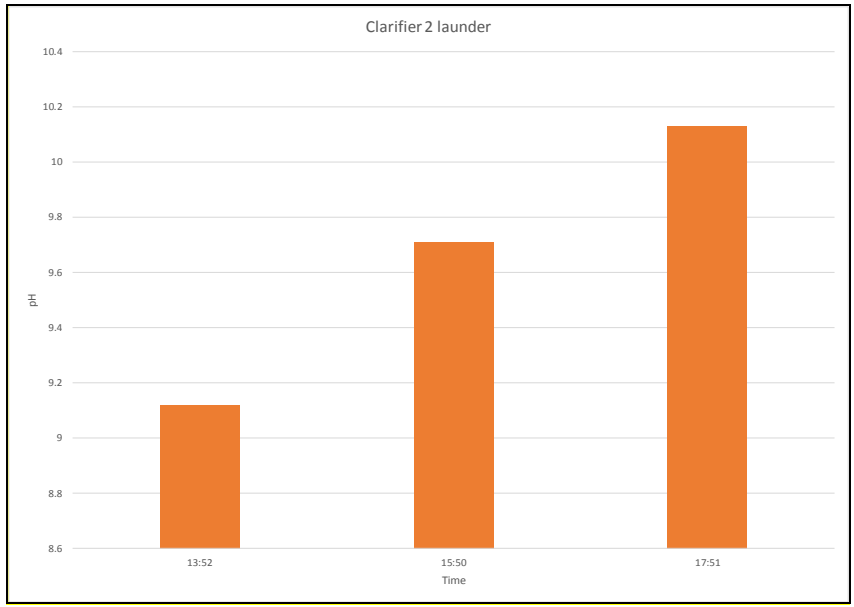

Fig.8: clarifier 1 treated water $\mathrm{pH}$

Two sets of samples were taken to the laboratory for $\mathrm{P}$ and $\mathrm{M}$ alkalinity analysis. Table VII shows the optimisation results from the laboratory. Though the laboratory results do not indicate an achieved optimum $\mathrm{pH}$ from clarifier 2, the chemistry performance for clarifier 2 is showing an improvement. An increase in $\mathrm{pH}$ to just above 10 can be seen from clarifier 2 center cone. This confirms the trend observed in Fig 7. The expectation was for the alkalinity relationship to be $2 \mathrm{P}=\mathrm{M}$, and it is unfortunate that during the test, optimum conditions were not met. This was due to the challenges experience in the power plant and the test had to be placed on hold.

TABLE VII: OPTIMISATION LABORATORY RESULTS

\begin{tabular}{|c|c|c|c|c|c|}
\hline \multicolumn{6}{|c|}{ Optimisation laboratory results } \\
\hline \multicolumn{6}{|l|}{ First set } \\
\hline Sample Point & pH & P-alk (ppm) & M alk & $2 P$ & $\begin{array}{l}\text { Alkalinity } \\
\text { Relationship }\end{array}$ \\
\hline Clarifier 1 & & & & & \\
\hline Centre cone & 9.217 & 30.8 & 212.5 & 61.6 & $2 \mathrm{P}<\mathrm{M}$ \\
\hline \multicolumn{6}{|l|}{ Clarifier 2} \\
\hline Centre cone & 9.17 & 31.3 & 249 & 62.6 & $2 \mathrm{P}<\mathrm{M}$ \\
\hline Launder 1 & 9.214 & 32.8 & 208.9 & 65.6 & $2 \mathrm{P}<\mathrm{M}$ \\
\hline \multicolumn{6}{|c|}{ Second set } \\
\hline Clarifier 1 & & & & & \\
\hline Centre cone & 9.659 & 47 & 173.7 & 94 & $2 \mathrm{P}<\mathrm{M}$ \\
\hline Clarifier 2 & & & & & \\
\hline Centre cone & 10.056 & 72.2 & 219.2 & 144.4 & $2 \mathrm{P}<\mathrm{M}$ \\
\hline Launder 1 & 9.514 & 46.7 & 198.9 & 93.4 & $2 \mathrm{P}<\mathrm{M}$ \\
\hline Launder 2 & 9.634 & 54.4 & 226.4 & 108.8 & $2 \mathrm{P}<\mathrm{M}$ \\
\hline
\end{tabular}

\section{CONCLUSIONS}

The results from the optimisation trial show that lime was under dosed. Clarifier 1 and 2 average $\mathrm{pH}$ results on the center cone are 9.4 and 10 respectively. The steady increase in $\mathrm{pH}$ does indicates that lime was being injected in to the clarifiers. From the results it is evident that the optimum $\mathrm{pH}$ was never reached. This is due to the limited time that was given to conduct the trial. Great results could have been obtained, however serious challenges were experienced with regards to plant, chemicals and spares availability.

\section{ACKNOWLEDGMENT}

The authors are grateful of the financial support from Eskom; Author EFK acknowledged the financial support from the National Research Foundation (NRF) in South Africa (Grant No: 120323); Any opinion, findings and conclusions or recommendations expressed in this material are those of the authors and therefore the NRF does not accept any liability in regard thereto.

\section{REFERENCES}

[1] Mkabane, P.T., Effluent treatment and its re-use for the Kriel Power Station. 2015, North-West University (South Africa), Potchefstroom Campus.

[2] August, J., Best Management Practice and Guidance Manual for Cooling Towers. 2005.

[3] Keister, T., Cooling Water Management Basic Principles and Technology. Pennsylvania, ProChemTech International, Inc, 2008.

[4] McCoy, J.W., The chemical treatment of cooling water. 1974: Chemical Publishing Company New York.

[5] Fosso-Kankeu, E., et al. Investigation of the potential of monomeric and polymeric coagulants in the treatment of raw water used at a coal-fired power station. in 9th Int'l Conference on Advances in Science, Engineering, Technology \& Waste Management (ASETWM-17). 2017.

[6] Van der Linde, J., et al. Removal of Total Hardness and Alkalinity from RO-Reject water. in 9th Int'l Conference on Advances in Science, Engineering, Technology \& Waste Management (ASETWM-17). 2017.

[7] der Linde, V., et al., Flocculant types and operating conditions influencing particles settling rates in feed water used at a coal power plant. 2019.

[8] der Linde, V., et al., Investigation of effective chemical flocculation conditions for the treatment of reverse osmosis reject water from coal power plant: a case study. 2020.

[9] Frayne, C., Cooling water treatment: Principles and practice. 1999: Chemical Publishing Company New York.

[10] Edzwald, J.K., Water Quality and Treatment A Handbook on Drinking Water. 2010: McGrawHill.

[11] Liang, L.-S., D.J. Goldstein, and I.W. Wei, Chemistry of lime-soda softening of cooling water. 1980.

[12] Takahashi, K., Blow system and a method of use therefor in controlling the quality of recycle cooling water in a cooling tower. 1995, Google Patents.

[13] Venter, P., Determine Optimum pH for CW Treatment 2010.

[14] Technology, E.W.S.a., Chemistry and Microbiology Standard for Condenser Cooling Water 2016. 240-55864767.

[15] Boyd, C.E., C.S. Tucker, and B. Somridhivej, Alkalinity and hardness: critical but elusive concepts in aquaculture. Journal of the World Aquaculture Society, 2016. 47(1): p. 6-41. https://doi.org/10.1111/jwas.12241

[16] Bratby, J., Coagulation and flocculation in water and wastewater treatment. 2016: IWA publishing. https://doi.org/10.2166/9781780407500

[17] Hudson Jr, H.E. and E. Wagner, Conduct and uses of jar tests. Journal-American Water Works Association, 1981. 73(4): p. 218-223. https://doi.org/10.1002/j.1551-8833.1981.tb04683.x

[18] Cohen, J.M., Improved jar test procedure. Journal (American Water Works Association), 1957. 49(11): p. 1425-1431. https://doi.org/10.1002/j.1551-8833.1957.tb15499.x

[19] McDonald, Alkalinity \&pH relationships. 2006 